DOI https://doi.org/10.18551/rjoas.2018-07.23

\title{
THE “GADJAH MADA” PROGRAM IMPLEMENTATION TO ACELERATE BHABINKAMTIBNAS' ROLES AND FUNCTIONS
}

\author{
Purbantoro Adam \\ Postgraduate School, Airlangga University, Indonesia \\ E-mail: adam.akpol2006@gmail.com
}

\begin{abstract}
The acceleration of roles and functions of Bhabinkamtibnas of Gresik Police resort is the result of working performance improvement in the form of quantity indicators. The indicator shows an improvement in the amount of visit that they made and the working effectiveness. Quality of work determines the quality of problem mapping in more details; the problems do not only limit on safeness and order issues, but also in social problems. Personal qualities are the support from transformational within Gadjah Mada program. Fortunately, those problems do not postpone the program target as each of them is well overcome.
\end{abstract}

\section{KEY WORDS}

Role acceleration, Bhabinkamtibnas, working Improvement, Gadjah Mada team.

Started from several problems occurred as the result of Bhabinkamtibnas function implementation errors, Gresik Police Resort declare the Polres Head Instruction number: Sprint/484/VI/2016, on June $4^{\text {th }}$ 2016. It deploys an innovations program called "Gadjah Mada" as the abbreviations of Antisipasi Kejahatan serta Penyelesaian Masalah Masyarakat Desa (Crime Anticipation and Problem Settlement of Village Society). One of their sub program is Quick Win and Polri Grand Strategy to enhance the Police Image among societies as the protector and of people by always visiting the village and overcome if the possible threat is found in quick time. Gadjah Mada program is the implementation and system of Binmas and Bhabinkamtibnas function by doing visit to Tomas, Toda, and Society. The officer must be proactive while communicating with people. So, the officer would detect the threat or problems earlier known as IPOLEKSOSSBUDKAM which is developing among society and being protected by Law article 26 Perkap number 3 of 2015 about Polmas. From the amount of visit officer could make, the program allows them to have more maximum visits in shorter time and better result. Within Gadjah Mada Program, the three pillars of government will be consolidated; they are government, Police and Military. It will be easier for them to map their role and function in overcoming social problems among society in the name of Gadjah Mada Team.

The Gadjah Mada team was meant to do direct service to people about the problems that they are having with or any future threats. The team was split into four divisions, each division hold up to 25 personnel; the personnel consist of traffic police, detective, Drugs Police, Babinkamtibnas and the staff such as medical personnel. The medical personnel are very important if the team found a civilian with bad health condition and could not afford medicine in time. In total, the gadjah mada team possessed 100 personnel which often called the 100 consultants. These 100 personnel is very important as the resort police of Gresik realised that importance of Police officers service which function as analysis towards the root problems found among villagers as it is the most fragile area to ignite a conflict. The 100 consultants is a new innovation for the concept of Bhabinkamtibnas function implementation. Door to door is the method used by the team to make a visit in villages? The visit will make a record to the head of family identity within the members of family itself. The information will be informed in the form of Visit Report. The consultant must able to detect early threat or problems, they must evaluate and analysis if the threat will be a serious problem. Thus, the solution must also be early invented to overcome the upcoming threat within villages. The consultant could commence a mediation or negotiation to the recent problems that they handle. The preventive activity also delivered by socialising and making 
publication of any regulation that the villagers need to be aware of. The information report must be handed to the leader of the team every week or every month, the report will be forwarded to Head of Gresik Police.

The differences between old program, Polmas, and the new program, Gadjah Mada, is the switching process of Community Policing into Democratic Policing. The difference lies in the method of problem overcoming method. The community policing includes society in overcoming with solutions that they offer through Police and Society Mediation Forum and Police and Society Council. Meanwhile, in democratic policing, not all people could participate in policy making process. Some people will attend the meeting as representation of the society, thus, the meeting will not consume much time. Moreover, the government representation will also come to the meeting. The meeting will mostly discuss each problem faced by each family which is reported from the head of family in Activity Report as result of 100 consultants' job. If there were 1000 head of family in a village, by estimating 7 family visits in a day for each personnel, the team could afford 700 visits in a day. The target will be fulfilled in two days. It is different from former method which gather able to information of 1000 family in 1,5 years. Moreover, the new concept has $75 \%$ of success rate in overcoming problems within 12 days.

\section{METHODS OF RESEARCH}

The study uses descriptive qualitative method to describe the recent problems which still intact. It consists of note taking, description, analysis, and interpretation the recent conditions. In other words, the descriptive qualitative is meant to collect information of recent conditions: the descriptive qualitative is designed to collect information of recent issues; in one hand, descriptive qualitative is a method to commence research on human status community, an object to be described, an image of systematic way, factual and accurate information or phenomenon that become problem of the study.

\section{DISCUSSION OF RESULTS}

The Implementation of Gadjah Mada Program To Accelerate the Roles and Function of Bhabinkamtbnas. To assess whether the improvement of new concept, Gadjah Mada, is successful or not, the study uses Working Performance Acceleration Assessment proposed by Gomez. It consist of Quantity of work, Quality of work, Job Knowledge, Creativeness, Cooperation, Dependability, Initiative, and Personal Qualities. Each stat will be discussed as follow:

- Quantity of Work:

Indicator Quantity of work as an indicator of the assessment of working performance is an indicator of the quantity or number of job achievements that have increased significantly. From Gresik Polres data, the quantity of Gajah Mada team's performance with its 100 Consultant program has been improved significantly. The performance improvement especially from the number of successful targets must be achieved by Bhabinkamtibmas in the form of increasing intensity of officer visit to the residents.

For example, the implementation of Gajah Mada team activity is conducted in Mulung Village Driyorejo Gresik Subdistrict, Petiken Village, Driyorejo Gresik Sub-District, Banjaran Village Driyorejo Gresik Sub-district, Sumput Village Driyorejo Gresik Sub-district. Maximum performance target is at $478 \mathrm{HH}$. With the working pattern of Team Gajah Mada involving 100 consultants and other policy implementing elements, with targeted visits, hospitality and face-to-face in $478 \mathrm{HHs}, 398$ families can be terialized or about $92 \%$ realized. While that can not be visited because majority of the population of 4 villages are Workers / Factory Workers. If carried out with the old pattern of relying on a bhabinkamtibmas with a range of day-to-day visits, hospitality and face-to-face elements of targeted communities, then at least can only do 2 times per day and for visits in 398 families as realized by Tim Gajah Mada, then with the old Pattern will take about 199 days to realize the number of visits, hospitality and face-to-face at $398 \mathrm{HH}$. 
- Quality of work:

Fasten working performance within quality of work indicator is goal of the stat based on the requirement of preparation and synchronization. Face to face communication method is used while Gadjah Mada team executing the order. They also commence two way reciprocal communications, within personnel (intern) communication; they must reveal the frame of reference of the society as their target. It could be their orientation by complementing the situation factor. To enhance the quality of their working performance, the team must focus on the current problem among society. Team must not use linear one way method while looking for the cause of the problem. In other word, they must apply circular communication method. The process is already in line with the original target of Gadjah mada team which is family as the smallest community among the society. The result of Gadjah mada programs are mostly satisfied, the quality of problem mapping of the team is improving, it detects not only the problem from inner Bhabinkamtibnas, but also the other problem that society has raised.

This satisfied result come from the personnel composition who come from different backgrounds. Not only police, the personnel also filled with manucipal police, general authorization department, and etc. the complexity of problem will be easier to tale down as the composition of personnel are vary. This is align with the definition of working performance quality stated in police head regulation number 3 of 2015 about Polmas within article C, D, and E stated that The successfulness of Bhabinkamtibnas and Polmas means the improvement of working motivation to serve and give service to the society as the duty of public servants. Another indicator is the improvement of the time they respond to any isuue among society.

- Job knowledge:

This stat is very crucial to determine the successfulness of the team's operation. Because, the amount of knowledge possessed by the team members determine the amount of information and study result of the team.

Unique skill is needed for bhabinkamtibnas to enhance their role and function. The Chief regulation article 29 number 03 of 2015 state that the personnel must possess the skills as follow: Early detection; Social communication; Negotiation and meditation; Leadership; Problem solving.

Members with sufficient knowledge will improve the efficiency of task execution. But for members of the Team who do not have enough knowledge, it will hamper its performance. Financial waste, time and energy and other factors will be done by less knowledgeable Team members. This waste will inevitably hinder the achievement of organizational goals. According to Dale knowledge possessed by a person can be categorized in two types, namely: based knowledge and knowledge that is not based. If associated with the demands of the ability of members or consultants of the Gajah Mada Program, then to improve the ability of early detection; social communication; negotiation and mediation; leadership; and social problem solving, according to Spencer, the increase in knowledge if the competence of members in the realm of analytical thinking (AT), conceptual thinking (CT), technical / professional / managerial expertise (EXP) as explained below:

- Analytical thinking is a skill to detect problems and situation to process them into small details of it, or a skill to gather the implication of a situation in details. In general, this competency allows the personnel to think in systematic and analytic way toward complex situation. To improve analytical thinking of Gadjah Mada personnel, apply a significant workshop of intensive training. Before the team enter the field, they must participate in analytical thinking training program 3-2 times in 2,5 months. It takes place in Gresik Police Resort ballroom by inviting the experts to train them. The discussion focused on problem solving of social issues. The evaluation process is maintained to conclude whether the team improves their analytical thinking skill or not.

- Conceptual thinking is a process of understanding by gathering small details and put them together to revel bigger picture of the issue. In practice, the sample taken from 
Sumput village revealed that the team detects drugs and liquor issue. Thus, the questionnaire raised when visiting the village lead to the description of criminals identity who store and deliver the stuff, the team must get the information of the place and time of the transaction, another important information to gather is the modus of the criminals. In other hand, sample taken in Mulung Village, the problem and issues found there are mainly about agrarian. Then, the questionnaire for the society must be about agrarian lawsuit case, land acquisition confclict between both parties. By using conceptual thinking, the team will acquire bigger image of the issue and let them to chose best option for the current problems within different villages.

- Expertise (EXP) is one of job-related knowledge (technical, professional, or managerial), it is also the motivation to extend, utilize, and distribute that knowledge. This is a form of implementation of the capacity obligations that must be owned in accordance with The Chief Regulation Article 29 of number3 of 2015 which has the ability in social communication, negotiation, mediation and conduct leadership in dialogue sessions with citizens. To train communication skills, negotiation, mediation and lead dialogue sessions, each member is equipped with IPS (Inter Personal Skill) Training 2 times a Meeting and 1 time and Simulation for 2.5 months at Polres Gresik. The training provided for IPS is a direct communication technique (Direct Communication). Direct communication is communication between communicator with face-to-face communication.

Creativeness is a statement meant to overcome a current issue. To enhance this ability, the head of the team must provide equal chance for each members to contribute and deliver their idea in democratic way. Every member, during evaluation process, must able to perform their creativity to overcome the problem by using new method and finding that they invent. Within this stat, the Gadjah mada team is able to create an application called Go Sigap lead by the head of Police Resort to support Gadjah Mada program. It is a multifunction app which is available on Playstore, there are some features that people can use as follow:

- Panic button;

- Laporan informasi (Information Report);

- Notifikasi permintaan bantuan dari Polri(Notification of Polri Aid);

- Info dan Berita(Information and News);

- Alamat penting(important numbers).

In order to use maximum features of the app, the society must do registration by filling their identity card number, name, adress, phone number and picture of ID. The early information that people can get from the app are mainly about:

- Info Bencana (disaster information);

- Info unjuk rasa/ kerusuhan(Demonstration/Rally Information);

- Info kemacetan (Traffic Information);

- Info kegiatan masyarakat (Social Events);

- Info update cuaca (Whether Cast).

The unique feature, panic button, will allow the society to send their personal information including the current position to Gresik Police Resort. The current position of the sender will be automacially updated every one minute when this feature is activated.

Cooperation is the vailability to work with others. While overcoming the problems of social issues, gadjah mada always coordinate and coorperate with another institution to create effeciency of time. One of example is when the team try to overcome the problem in Driyorejo, the team helps shorten the negotiation time between policy makers and another party. The case details are: The village budget is promised to obtain 13 billion rupiahs as compensation for their used land by other sector. Unfortunately, the promise is broken and there are 11 documents waiting for next land compensation acquisition. To solve such problem, the team coordinates with Police Resort, head of Sub-district, konimayaron, BPN, Head of Mulung village. They socialise the law number 02 of 2012 about land acuisition for public purpose. It stated that the personal land will have compensation, the documents will 
be delivered to government but not for village land as stated in law number 2 of 2012, the village land, as state asset, will not receive any compensation

Dependability is an awareness that could be trusted on its presence and working complement. The $100 \%$ attendance of gadjah mada team is mandatory, all 100 consultants must able to overun the deadline of their target. They must aware of their scheduling process and their shift rolling. The 100 consultants are chosen from all police officers of Gresik Regency, they must be well prepared, the candidates attendance list must be on $100 \%$ from their previous office, the replacement must be very quick if one of their personnel is unable to attend the program.

Initiative is a new motivation while receiving such bigger responsibility. The initiative of the team is well applied on the field. The early program already blocked by financial factor, but this obstacle did not make the team lost the motivation to complete their mission, the personnels are willing to use their own budget if the successfullnes of mission was so depend on it. Beside, it is not easy to apply every single theories they have learnt on training, some community on villages are hard to be compromised with, good initiative is very needed on such situation. thenew motivation while receiving bigger responsibility must always be plotted on the soul of each personnel.

Personal qualities is about leadership, personality, hospitality, and personal integrity. In this study the authors emphasize the leadership model as personal qualities that have a big effect on the achievement of bhabinkamtibmas performance acceleration. The leadership model of Gresik Police Chief when going to make innovation of Gajah Mada Program is a model of Transformational leadership. One of Kapolres' personal qualities as a Leader with transformational character is acting organizational renewal agency that created the Gajah Mada Program as an innovative program with the speed of solving community and social problems. The leader of this type analyzes the old ways in which community policing is considered ineffective in maximizing the role of bhabinkamtibmas. The ineffectiveness of problem-solving and the settlement of community and other social problems with the community policing method also raises the reform discourse of the leadership to accelerate the settlement of the kamtibmas and social problems.

The obstacles during Gadjah mada program implementation and the mechanism solving. These are the problems found during the implementation of gadjah mada program:

The main problem of this issue is the result of there is no certain regulation from Chief Regulation of Indonesian Police. The implementation of this program is only protected from Police Resort Regulation of Gresik number: sprin/484/VI/2016 of $4^{\text {th }}$ June 2016 about the 100 consultant formation of Gresik Regency. Because of this issue, the problems found are as follow:

- There is no standardized/legal definition of democratic policing applied towards Gadjah Mada program;

- The strategies to achieve mission and vission of the programs are not in details starting from the implementation of starting strategy of association phase, the problem solving mechanism details, Polri Service, and etc;

- Each mandatory duty for each pilars, (Government, Polri, and TNI) are not informed in details;

- There is no clear financial report of DIPA (The Administration Budget List) for Gadjah Mada Gresik Program.

Most problem occurs as the result of undesentralisation of the policy among all indonesian regency because there is no policy support from the central unit (Kapolri)

The implementation of Gadjah Mada Program innovation is a product of complexity policy with many obstacles.that is why, the implementation complexity scale is higher than other program. Thus, the administration policy become one of major issue of this program.

The financial administration issue plays important factor for the development of gadjah mada program.

Thye gadjah mada team must, at least, commence a visit to society once a month. But, they could make more visits based on the current situtaion of the village. 
According to the administration data of financial distribution of 2017, which covers each financial departments expenditure, Unit and Polsek Ranks and technical guidance of budget absorption. For Gresik Police resort financial administration data of 2016, it has Rp. 82.766.408.000 for staff expenditure, Rp. 33.877.057.000 for commodities expenditure allocation, and Rp. 30.000.000 for capital allocation. Thus, Gresik Police Resort covers Rp. 116.673.465.000 in total for financial support of 2016. Then for the budget allocation Polres Gresik 2017 is divided into three types of expenditure ie employee expenditure amounting to 100.097.900.000 and goods expenditure of Rp. 38,929,144,000 and capital expenditure of Rp. 407.614.000 with total budget support received by Polres Gresik Rp. 139.434658.

Throughout development and planning administration, the Local Police of Eastern Java Police does not support the financial of Gadjah mada program, it is stated on DIPA of 2017. thus, because of there is no early support for 100 consitants of gadjah mada personnels, the team only receive Rp.5000/day for meals, this is far from the word enough to cover the expenditure for each personnels. Even, there is no clear supporting financial for the next 2018 administration data, because the program is only applied only in Gresik Regency.

That is why, the Chief of Gresik Police Resort made an attemppt of grant funds offer. The attempt was successfull, the chief obtain additional financial aid about Rp. 250.000.000,-. This support is literary mandatory for Gresik government as Police is one of their major partner in Forkopimda (Communication Forum of Local Leaders). By this additional funds, the team will be able to maintain one of their product Go Sigap. According to M. Narafin, the amount of financial aid is a short-term funds from time expenditure perspective. Short-term budgets are budgets made with the longest period of time up to a year in order to support performance. Whereas expected from the availability of budget for the implementation of the Gajah Mada Program is a type of fixed budget, continuous and in the long term. So,there will be evaluation and projection performance targets in more than a year.

Unfortunately, the grant fund for the next season of 2018 remains unclear. Thus, the only way to obtain additional financial aid is to turn the program into national scale from central government.

Society Charaters Issue. In gneral, the society accepts and appreciate the gadjah mada program in positive ways as stated by several consultants below.

According to Hamid Rusdi, Binmas Members of Gresik Polres:

The villagers are very excited to wait the arrival of gadjah mada team when visited their village. Because, the villagers has received information before that the problems or their aspiration will be well handled if they store it to gadjah mada team visit. That is why, the visit is very valuable in the eyes of the villagers. Beofre the team commence the questionnaires to the villagers, the team ionforms them that the identity of informants will remain in secret and safe. Thus, the people will have no fear to express any thought and problems that hold their fear in living their life. This is already prooved by every names of the people visited by the team within diffrent villages.

According to Sukarto, Binmas Members of Gresik Polres:

On early visit, the villagers are very cooperative when they are being interviewed by the team. They help the personnels a lot to gather more datas about the problems or issues raised on the village. The villagers provide team with details of information in efficient ways.

The villagers answered all questions honestly, the did not make the interview difficult. In return, they feel happy as one of representation of the government make a special visit by going after their house.

This method known as blusukan in Indonesia, it is very efficient to be applied in vast area of indonesia. Thus, people support and feel respected as the government take care of them by doing visit directly to thier house.

The solidarity among people in village is still stronger than city. That is why, the bound and connection between team and villagers are easily formed as the villagers are full of respects and honor. Solidarity is a situation between individuals or communities which is based on the morals and believes of both parties consolidated by same past experience 
which forms same emotional condition. Thus, people will help each other if one of the member need a hand. For example, if one of village commence a wedding, circumcision, and demise occasions, people will automatically help the home without asking them before. The amount of people who participate in occasion is not the same between village and city. For example, in Gresik Regency, the amount of people who participate in demision, it will not exceed hundred, they will help the home to take care of the body into the graveyard. But, if it is about wedding party, it will exceed hundreds number of people participating in the party. The participation could be more than 4-5 neighbiourhoods, the amount will increase if the party holder is public figures.

Another issue faced by the team is the homogeneity of villagers, it apperas that such issu becomes problem for gadjah mada program within one area. For example, there is a certain village whose people are dominated by labor company, the team could not make a visit earlier at 5 p.m. because, the majority of villagers are still not coming home from their workplace. This case was experienced by the team based on the interview with one of personnel below: "many of the villagers house are empty as they still working on the factore when we made visit".

The team could not hesitate their visit on schedule if the villagers are still working. The team must not broke the ethic rule if they insist to make a visit on that time. This issue affects the precentage of visit that must be re-schedulde by the team.

From the issues above, Gresik Police Sub-precinct must coordinates in advance with the bhabinkamtibmas of the area to be visited whether there is a plan of celebration on its territory or not. But for the problem of the incident of death, it can not be predicted before so the existing solution, when a member finds its territory there is an incident that befell the residents, the Team will coordinate through WhatsApp group Team Member of Gajah Mada to check the number of the last visit is above $90 \%$ or not. If it has reached $90 \%$, the members can coordinate with the leaderto abort the visit. In case after coordinating with other teams, the number of visits is less than $90 \%$, the team will coordinate with the leader whether the visit is postponed or the target percentage visits are decreaseed within the area.

\section{CONCLUSION}

Gadjah Mada Program accelerates the role and function of bhabinkamtibnas through several indocators as follow:

- Quantity of work, the amount of visits to accelerate the program to be finished is around 478 families or $92 \%$ in a day. In time efficiency, the program reach great improvements about $9.447 \%$ (nine thousand and four hundred fouty seven percent);

- Quality of work, it measures the more details of problem mapping by the team, the problems must not only focused on the orders and safety of society issue, but also other social issues;

- Job knowledge covers the ability of gadjah mada team to do analytical thinking (AT), conceptual thinking (CT), and technical/professional/managerial expertise (EXP);

- Creativeness is the varities options proposed by the members within leader verification and approval, the product is applied on Go Sigap Application which is available on Playstore. In meantime, the product is still on maintenance and development;

- Cooperation is the way of the p[ersonnel to link up with another important institutions, it improves the time efficiency as many social problems solved quickly;

- Depenadability is represented in $100 \%$ attendance responsibility for the personnels to solve the issues in maximum efforts;

- Initiative is the way of the team to solve problem by initiation of the team's members on the field;

- Personal qualities cover the transformational leadership in gadjah mada team to better than before.

There is no significant regulation for gadjah mada team that include in Police 
Regulation, it causes the program is not include on one of national democratic policing which is applied in the program. The strategies to achieve mission and visions of the program are still blur on each pilars (Governments, Police, and Military). Moreover, there is no significant plotting of DIPA for gadjah mada program of Gresik. Eventhogh, the tehnical regulation could be maintained by internal Gresik Governance through skep Polres, the impact is still to low to affect entire Gresik are. related to budget plotting for more maximal program implementation as well as various policy support from Police Unity at a higher level than Polres level. The second issue concerns the input of operational budget. Within the development and planning program of Gadjah Mada plotting financial administration through DIPA 2017 and 2018, it delayed some mission of the team. Eventhough there is a short term financial aid of grant fund commenced by Head of Gresik Police Resort, it does not enough to continue the program. Thus, transforming the program into nastional scale is the only option to support the program. The third issue is about the characters of villagers. In some occasions, the villagers are willing to help each other when another villager need a lending hand. As a result, the team canceled their visit to that place. Thus, coordination with local bhabinkamtibnas personnel is mandatory to decide whether the village is able to be visited or not. In case of unpredictable occasion such as demise, the visit will be directly canceled to respect them. Another problem is the homogenity of the villagers who possesed same occupation as labour. The team will not able to make a visit before 5 p.m, as the villagers are still working on the factory. The coordination with leaders are very important to make certain schedule on that uniqe are. Another way is by periodically check other team visit precentage to solve this kind of problem.

\section{REFERENCES}

1. Doyle Paul Johnson, Teori Sosiologi Klasik dan Modern, Gramedia Pustaka, Jakarta, 1994.

2. Faustino Cardoso Gomes, Manajemen Sumber Daya Manusia, Penerbit Andi, Yogyakarta, 2003.

3. Nafarin M., Penganggaran Perusahaan. Edisi Ketiga, Penerbit Salemba Empat, Jakarta, 2007.

4. Onong Uchjana Effendy, Teori dan Filsafat Komunikasi, PT. Citra Aditya Bakti, Bandung, 2003.

5. Sudarmanto, Kinerja dan Pengembangan Kompetensi SDM (Teori, Dimensi Pengukuran dan Implementasi dalam Organisasi). Pustaka Pelajar, Yogyakarta, 2009.

6. Sutoto Amriyati, dkk. Kinerja perawat ditinjau dari lingkungan kerja dan karakteristik individu, Jurnal manajemen pelayanan kesehatan Vol. 06 No 01.

7. Suwarno Pengembangan Tes Diagnostik dalam Pembelajaran, Pustaka Belajar, Yogyakarta, 2013.

8. Smith T.V. and Eduard C. Lindeman, The Democratic Way of Life, The New American Library, New York, 1956. 